\title{
MAIZE VARIETIES FOR BABY CORN YIELD AND POST-HARVEST QUALITY UNDER ORGANIC CROPPING
}

\author{
VARIEDADES DE MILHO PARA PRODUÇÃO DE MINIMILHO E QUALIDADE \\ PÓS-COLHEITA EM SISTEMA ORGÂNICO DE CULTIVO
}

\section{Adelmary Prestes LOPES ${ }^{1}$; Lúcia Helena Pereira NÓBREGA ${ }^{2}$; Fábio Palczewski PACHECO ${ }^{3}$; Claudia Tatiana Araujo da CRUZ-SILVA ${ }^{4}$}

1. Engenheira Agrícola, Mestre em Engenharia Agrícola pelo Programa de Pós-graduação em Engenharia Agrícola - PGEAGRI Centro de Ciências Exatas e Tecnológicas - CCET, Universidade Estadual do Oeste do Paraná - UNIOESTE, Cascavel, PR, Brasil; 2. Engenheira Agrônoma, Professora Associada, PGEAGRI - CCET, UNIOESTE, Cascavel, PR, Brasil; 3 Engenheiro Agrícola, Doutor, UTFPR - campus Medianeira, Medianeira, PR, Brasil; 4. Bióloga, Doutora, PGEAGRI - CCET, UNIOESTE, Cascavel, PR, Brasil.

\begin{abstract}
This study aimed to evaluate five corn varieties for baby corn yield and post-harvest quality under organic crop. The experimental design was completely randomized with four replications to evaluate the yield components and post-harvest of the studied product in 5 × 2 × 4 factorial, five varieties (IPR 114, PC 0402, PC 0404, BR 106 and BRS Angela) and two conditioning ways in the refrigerator (with and without straw) and four storage periods (0, 4, 8 and 12 days). Yield components such as spikes number per plant, plant height, height first spike, spike length without straw and with straw, spike diameter with straw and without straw, spike with straw weight and without straw, baby corn yield with straw and without straw, commercial production of baby corn without straw, commercial yield of baby corn were evaluated. For its post-harvest of product were analyzed weight loss and color parameters $\left(\mathrm{L}^{*}, \mathrm{a}^{*}, \mathrm{~b}^{*}, \mathrm{C}^{*}\right.$ and $\left.\mathrm{H}^{*}\right)$ in $0,4,8$ and 12 day storage periods. The results showed that the varieties were classified according to the commercial standards for both diameter and length. Thus, PC 0404 was the most suitable for obtaining baby corn. The PC 0402 showed the best results for color parameters $\mathrm{L}^{*}, \mathrm{a}^{*}, \mathrm{~b}^{*}, \mathrm{C}^{*}, \mathrm{H}^{*}$ and the lowest weight loss during storage periods.
\end{abstract}

KEYWORDS: Storage. Yield. Yield components. Zea mays.

\section{INTRODUCTION}

Maize (Zea mays), due to its productive potential, chemical composition and nutritional value, is one of the most important cropped and consumed cereals. It is used in several nourishing forms such as dried and green grains, "in natura", processed or as baby corn. Baby corn is the name given to young corn spikes, when they are early harvested, almost two days after the stigmas onset before fecundation (RAUPP et al., 2008; PEREIRA FILHO et al., 2009). Since, it is classified as horticultural activity; there is some need to staggered yield to meet its demand (PEREIRA FILHO; CRUZ, 2001). Among the marketing forms, it can be done with or without straw, minimally processed or canned, in order to improve the product.

Baby corn can be obtained from commercial seed maize varieties and sown in high density (PEREIRA FILHO, 2008). Several studies have been carried out regarding the baby corn management in Brazil, such as corn genotypes in order to identify the most appropriate ones and obtain baby corn (PEREIRA FILHO; GAMA, 2001; PINHO et al., 2003; RODRIGUES et al., 2004). Besides, the activity lacks important information about some conditions to keep appropriate characteristics, and provide the highest quality marketing of this product. The agricultural products usually have limited shelf life due to biochemical reactions of catabolic nature which increase with senescence, causing tissue death (HOJO et al., 2007). Green vegetables such as baby corn have their shelf life of post-harvest quality affected due to catabolic reactions, thus causing post-harvest losses (LANA, 2000). Baby corn has water as main constituent, so this required care in post-harvest, storage and marketing periods, to prevent weight loss, which will result in quantitative and nutritional quality losses (KADER, 1992).

Baby corn crop in agricultural Brazilian scenario, has not been widespread and it has a great potential concerning information about availability of specific yielding corn varieties and technological evaluation of this product. Thus, it is important and necessary to stimulate research on maize varieties behavior appropriate to this segment, better yield and post-harvest period in order to increase the shelf life of harvested products. This information is essential to research about this subject.

Thus, this study aimed to identify maize varieties for baby corn yield, determine yield components, evaluate the technological quality by determining the weight loss (ML) and color 
parameters $\left(\mathrm{L}^{*} \mathrm{a}^{*} \mathrm{~b}^{*}\right.$ and $\left.\mathrm{C}^{*} \mathrm{H}^{*}\right)$ in post-harvest product.

\section{MATERIAL AND METHODS}

The experiment was carried out from October to December 2011, in a private organic farm with 7.0 ha, placed in Colonia Barreiro, $10 \mathrm{~km}$ from Cascavel city. The geographic coordinates are the 24 and 56' southern latitude and 53 and 22' western longitude of Greenwich, with $685 \mathrm{~m}$ average altitude. The weather is humid subtropical (Cfa), with $1800 \mathrm{~mm}$ rainfall annual average, hot summers, frosts is not frequent .It thus no trains a lot during summertime. However, there is no dried defined season, whose averages are $20^{\circ} \mathrm{C}$ and for air relative humidity $75 \%$ (Caviglione et al., 2000).

The experimental soil area, according to the Brazilian System of Soil Classification is dystrophic Oxysoil Udic (USA, 1998) and flat relief (EMBRAPA, 2006). The area was divided into plots of $4.0 \mathrm{~m}$ long x $2.40 \mathrm{~m}$ wide. Each plot consisted of four rows of plants, spaced $0.80 \mathrm{~m}$ between rows, with four replications for each treatment, totaling 20 plots. Between the plots was included the distance of $1 \mathrm{~m}$ in order to eliminate the treatments influence. Each experimental unit consisted of $9.6 \mathrm{~m}^{2}$. The data were obtained from the two central use full rows, without considering $0.50 \mathrm{~m}$ a teach end of the row. Thus, the use full area consisted of $2.40 \mathrm{~m}^{2}$.

The evaluated maize varieties were: IPR114, PC0402, PC0404, BR106, BRS Angela, which were sown in the field on October $1^{\text {st }}, 2011$ whose density was 150,000 plants $\mathrm{ha}^{-1}$. The next day after beginning of blooming, the spikes that had an issuance of 2 to $3 \mathrm{~cm}$ silk length were harvested and considered viable to produce baby corn.

The measurement of plant height was based on the measure of the component plants of the full plot area. The measurement was from the soil surface to the insertion point of the highest leaf blade, calculated as an average of all plants. For the number of spikes plant ${ }^{-1}$, the spikes produced in the full plot area were collected. The average of the total number of spikes was calculated. And for insertion height of the first spike, it was considered the distance from the soil surface to the insertion point of the first spike formed in the stem, so, in all plants of the full plot area, measured then the averages of all heights were calculated.

The produced spikes were collected by plants of each use full plot area to determine: spikes length with and without straw, spike diameter with and without straw, spike weight with and without straw. These parameters were calculated to mean of all plants. To determinate the baby corn yield with and without straw was heavy harvested spikes in line use full plot area and converted to $10,000 \mathrm{~m}^{2}$ (1 ha).

Yield commercial data classification for baby corn without straw was based on the standard used for canning food industries: length from 4 to $12 \mathrm{~cm}$, diameter 1 to $1.8 \mathrm{~cm}$, cylindrical shape and color ranged from off white to light yellow. On the other hand, commercial yield baby corn was obtained from the division of commercial yield of baby corn without straw by commercial baby corn with straw. Twenty four spikes uniform size were harvested to evaluate of weight loss and color $\left(\mathrm{L}^{*}\right.$, $a^{*}, b^{*}, C^{*}$ and $\left.\mathrm{H}^{*}\right)$. These spike were obtained from the use full plot area at the first harvest. They were taken to the laboratory and placed to each treatment (two kinds of packaging - with and without straw). They were then stored in polyethylene bags, wrapped with stretchable polyvinyl chloride. One package stored three spikes of each treatment resulting in four replications. During 12 days they were kept under refrigeration at $5{ }^{\circ} \mathrm{C}$ and evaluated at $0,4,8$ and 12 day storage periods. Weight loss evaluation was calculated by Equation 1 and the results were expressed in percentage.

$$
\text { "WL }=[(\mathrm{IW})-\mathrm{WTI} /(\mathrm{IW})] * 100 "
$$

Equation (1)

Where:

$\mathrm{WL}=$ weight lost $(\%)$

IW = initial weight $(\mathrm{g})$;

$\mathrm{WTI}=$ weight at each time interval (g days-1);

The color $\left(\mathrm{L}^{*}, \mathrm{a}^{*}, \mathrm{~b}^{*}, \mathrm{C}^{*}\right.$ and $\left.\mathrm{H}^{*}\right)$ was determined on two sides of the sample. The colorimeter (Minolta ${ }^{\circledR}$ - Konica colorimeter) was used in the same period with the same spikes to determine weight loss. There adding was obtained by the system $L^{*}, a^{*}, b^{*}$ where $L^{*}$ values (brightness or luminosity) varied from zero (black) to 100 (white); $\mathrm{a}^{*}$ represents variation from $-\mathrm{a}^{*}$ (green) to $+\mathrm{a}^{*}$ (red) and $\mathrm{b}^{*}$, the variation was from $\mathrm{b}^{*}$ (blue) to $+\mathrm{b}^{*}$ (yellow); chroma coordinates $\left(\mathrm{C}^{*}\right)$ and hue $\left(\mathrm{H}^{*}\right)$.

The experimental design was completely randomized to evaluate yield components. Post harvested at a were in a $2 \times 5 \times 4$ factorial design (two conditioning forms - with and without straw, five cultivars - IPR114, PC0402, PC0404, BR106 e BRS Angela and four storage periods - $0,4,8$ and 12 days) with four replications.

Data were submitted to variance analysis and the averages were compared by the Scot t-Knott test $5 \%$ probability, using the statistical software version 
5.3 SISVAR (FERREIRA, 2003). Weight loss variable and color parameters $\left(\mathrm{L}^{*}, \mathrm{a}^{*}, \mathrm{~b}^{*}, \mathrm{C}^{*}\right.$ and $\left.\mathrm{H}^{*}\right)$ were evaluated by regression analysis.

\section{RESULTS AND DISCUSSION}

\section{Yield components evaluation}

The mean values obtained for plant height, number of spikes plant-1 and the first spike height are shown on Table1.

Table 1: Mean values of plant height, number of spikes plant-1 and the first spike height.

\begin{tabular}{cccc}
\hline Varieties & $\begin{array}{c}\text { plant height } \\
(\mathrm{m})\end{array}$ & $\begin{array}{c}\text { number of spikes } \\
\text { plant }^{-1}\end{array}$ & first spike height $(\mathrm{m})$ \\
\hline IPR 114 & $2.59 \mathrm{~b}$ & $2.25 \mathrm{a}$ & $1.20 \mathrm{a}$ \\
PC 0402 & $2.66 \mathrm{~b}$ & $2.75 \mathrm{a}$ & $1.22 \mathrm{a}$ \\
PC 0404 & $2.55 \mathrm{~b}$ & $2.25 \mathrm{a}$ & $1.22 \mathrm{a}$ \\
BRS Angela & $2.44 \mathrm{a}$ & $2.25 \mathrm{a}$ & $1.28 \mathrm{~b}$ \\
BR 106 & $2.59 \mathrm{~b}$ & $2.50 \mathrm{a}$ & $1.33 \mathrm{c}$ \\
\hline
\end{tabular}

Averages followed by the same letter in the column do not differ by themselves according to Scott-Knott test at $5 \%$ probability.

As PC 0402 variety showed the highest plant height and spikes, it was observed that this answer was superior than most of the studied materials (BR 106 and IPR 114 varieties). Sá; Ramalho and Souza Sobrinho (2003) studied ancient and modern maize varieties and found out values for plant height from 2.15 to $2.83 \mathrm{~m}$. Carvalho et al. (2010) also recorded average plant height between 2.37 to $2.53 \mathrm{~m}$.

Regarding the first spike height, it is observed that BR 106 and BRS Angela varieties had the best results, respectively, differing statistically from the others. There was no statistics difference for number of spikes per plant among the tested varieties.

The obtained averages for spike length without straw (SLWS), with straw (SLS), spike diameter without straw (SDWS), with straw (SDS), spike weight without straw (SWWS) and with straw (SWS) for the studied maize varieties are shown on Table 2.

Table 2. Mean values for spike length without straw (SLWS), with straw (SLS), spike diameter without straw (SDWS), with straw (SDS), spike weight without straw (SWWS) and with straw (SWS) for the studied maize varieties.

\begin{tabular}{lcccccc}
\hline Varieties & $\begin{array}{c}\text { SLWS } \\
(\mathrm{cm})\end{array}$ & $\begin{array}{c}\text { SLS } \\
(\mathrm{cm})\end{array}$ & $\begin{array}{c}\text { SDWS } \\
(\mathrm{cm})\end{array}$ & $\begin{array}{c}\text { SDS } \\
(\mathrm{cm})\end{array}$ & $\begin{array}{c}\text { SWWS } \\
(\mathrm{g})\end{array}$ & $\begin{array}{c}\text { SWS } \\
(\mathrm{g})\end{array}$ \\
\hline IPR 114 & $9.31 \mathrm{~b}$ & $20.95 \mathrm{a}$ & $1.59 \mathrm{a}$ & $2.32 \mathrm{a}$ & $14.37 \mathrm{a}$ & $51.29 \mathrm{c}$ \\
PC 0402 & $10.00 \mathrm{~b}$ & $21.41 \mathrm{~b}$ & $1.60 \mathrm{a}$ & $2.42 \mathrm{a}$ & $17.48 \mathrm{~b}$ & $57.09 \mathrm{~d}$ \\
PC 0404 & $9.31 \mathrm{~b}$ & $20.42 \mathrm{a}$ & $1.54 \mathrm{a}$ & $2.31 \mathrm{a}$ & $16.08 \mathrm{~b}$ & $46.80 \mathrm{~b}$ \\
BRS Ângela & $8.27 \mathrm{a}$ & $20.24 \mathrm{a}$ & $1.46 \mathrm{a}$ & $2.12 \mathrm{a}$ & $12.07 \mathrm{a}$ & $40.64 \mathrm{a}$ \\
BR 106 & $8.86 \mathrm{a}$ & $22.29 \mathrm{~b}$ & $1.47 \mathrm{a}$ & $2.32 \mathrm{a}$ & $12.52 \mathrm{a}$ & $54.83 \mathrm{~d}$ \\
\hline
\end{tabular}

Averages followed by the same letter in the column do not differ by themselves according to Scott-Knott test at $5 \%$ probability.

The BRS Angela and BR 106 varieties showed the smallest spikes, which is desirable for this kind of product. However, all varieties showed acceptable standards according to Rodrigues, Silva and Mori (2004), which should be from 4.5 to $10 \mathrm{~cm}$ long. This result coincides with those registered by Pereira et al. (2011) when evaluated the productive and commercial features of five baby corn varieties, whose spikes length was similar to this study.

BRS Angela variety presented the lowest mean length $(20.24 \mathrm{~cm})$ and diameter $(2.12 \mathrm{~cm})$ for spikes with straw. Meneghetti et al. (2008) in a study with the same popcorn variety (BRS Angela), found variation from 18.6 to $20.4 \mathrm{~cm}$ in length and for diameter, the variation was from 2.3 to $2.9 \mathrm{~cm}$, with a final average $2.6 \mathrm{~cm}$. The lowest diameter averages for spike without and with straw were observed in BRS Angela with 1.46 and $2.12 \mathrm{~cm}$ and BR 106 with mean values of 1.47 and $2.32 \mathrm{~cm}$, respectively. The highest mean values for diameters without and with straw were for PC 0402 variety with 1.60 and $2.42 \mathrm{~cm}$.

Regarding spikes without straw yield, PC 0402 and PC 0404 varieties differed significantly from IPR 114, BRS Angela and BR 106 varieties, which showed the best yield for spikes without 
straw, 17.48 and $16.08 \mathrm{~g}$, respectively. The lowest value for this feature was observed for BRS Angela $(12.07 \mathrm{~g})$.

PC 0402 and BR 106 varieties statistically differed from the others and showed the best spikes weights with straw, i.e., 57.09 and $54.83 \mathrm{~g}$, respectively. Raupp et al. (2008) evaluated maize varieties for baby corn spikes yield and found for weight without straw, averages ranging from 8.7 to $10.9 \mathrm{~g}$ in spike straw weight values from 39.6 to $42.7 \mathrm{~g}$. These results were inferior to those ones already found in the present study spikes weight without straw (12.07 to $14.48 \mathrm{~g}$ ) respectively. While for spikes weight with straw, the results were from 40.64 to $57.09 \mathrm{~g}$.

Considering spikelets yield with straw of five varieties, it was observed a variation from 6.096 kg ha-1 (BRS Angela) to $8.564 \mathrm{~kg}$ ha-1 (PC 0402). For spikelets yield without straw, the variations were from $1.811 \mathrm{~kg}$ ha-1 (BRS Angela) to $2.621 \mathrm{~kg}$ ha-1 (PC 0402) (Table 3). Raupp et al. (2008) studied density of 160.000 plants ha-1 and found an average value of $6.616 \mathrm{~kg}$ ha-1 for spikelets with straw and average value of $1.588 \mathrm{~kg}$ ha-1 without straw.

Table 3. Mean values for baby corn yield with straw (BYS) without straw (BYWS), commercial baby corn yield without straw (CBWS) and commercial baby corn income (CBI).

\begin{tabular}{lcccc}
\hline Varieties & $\begin{array}{c}\text { BYS } \\
\left(\mathrm{kg} \mathrm{ha}^{-1}\right)\end{array}$ & $\begin{array}{c}\text { BYWS } \\
\left(\mathrm{kg} \mathrm{ha}^{-1}\right)\end{array}$ & $\begin{array}{c}\text { CBWS } \\
\left(\mathrm{kg} \mathrm{ha}^{-1}\right)\end{array}$ & $\begin{array}{c}\text { CBI } \\
(\%)\end{array}$ \\
\hline IPR 114 & $7.693 \mathrm{c}$ & $2.156 \mathrm{a}$ & $1.833 \mathrm{a}$ & 23.82 \\
PC 0402 & $8.564 \mathrm{~d}$ & $2.621 \mathrm{~b}$ & $1.866 \mathrm{~b}$ & 21.78 \\
PC 0404 & $7.020 \mathrm{~b}$ & $2.413 \mathrm{~b}$ & $1.878 \mathrm{~b}$ & 26.75 \\
BRS Ângela & $6.096 \mathrm{a}$ & $1.811 \mathrm{a}$ & $1.565 \mathrm{a}$ & 25.67 \\
BR 106 & $8.225 \mathrm{~d}$ & $1.878 \mathrm{a}$ & $1.649 \mathrm{~b}$ & 20.04 \\
\hline
\end{tabular}

Averages followed by the same letter in the column do not differ by themselves according to Scott-Knott test at $5 \%$ probability.

PC 0404 and BRS Angela varieties can be highlighted due to their income (26.75 and 25.67\%, respectively). These answers were superior to those ones obtained by Meneghetti et al. (2008), who found an income of $18 \%$ for BRS Angela variety under irrigation management. Incomes of similar magnitude to the obtained results in this study were also observed by Raupp et al. (2008).

\section{Weight loss evaluation}

There was a $5 \%$ significant interaction of probability among varieties, packaging management and storage period on weight loss. It was observed that for both packing management with and without straw in spikes (Figures 1 and 2), the analyzed varieties showed similar behavior. It can also be observed that there was the same trend on baby corn varieties losing weight as they increased the storage period (days). Queiroz et al. (2010) studied the edible wrapping effect on baby corn postharvest conservation that was minimally processed. The authors observed significant linear increase in weight loss during 12 days of storage at $5^{\circ} \mathrm{C}$.

There was a $5 \%$ significant interaction among varieties, kind of packaging and storage period on weight loss. On Table 5, it can be seen the split among varieties and packaging (with or without straw) for weight loss (\%) during twelve days.

Table 5. Interaction sliced among varieties and packaging (with or without straw) for weight loss (\%) in baby corn spikes stored during twelve days

\begin{tabular}{lcc}
\hline & \multicolumn{2}{c}{ Stored packaging } \\
\cline { 2 - 3 } \multicolumn{1}{c}{ Varieties } & With straw & Without straw \\
\hline PC 0404 & $11.2 \mathrm{Ca}$ & $11.4 \mathrm{Ba}$ \\
IPR 114 & $8.0 \mathrm{Aa}$ & $11.1 \mathrm{Bb}$ \\
BRS Ângela & $8.8 \mathrm{Ba}$ & $9.7 \mathrm{Aa}$ \\
BR 106 & $7.9 \mathrm{Aa}$ & $8.9 \mathrm{Aa}$ \\
PC 0402 & $7.2 \mathrm{Aa}$ & $11.3 \mathrm{Bb}$ \\
\hline
\end{tabular}


At the end of the stored period (twelve days), PC 0404 variety had the highest average for weight loss differing significantly from the others, in both packaging, with and without straw. PC 0402, BR 106 and IPR 114 varieties in packaging with straw had the lowest weight losses followed by BRS Angela. As for the packaging without straw, PC 0402 and IPR 114 presented the greatest average values of loss, differing from BR 106 and BRS Angela (Table 5). There was the same behavior for weight loss of baby corn varieties as the storage

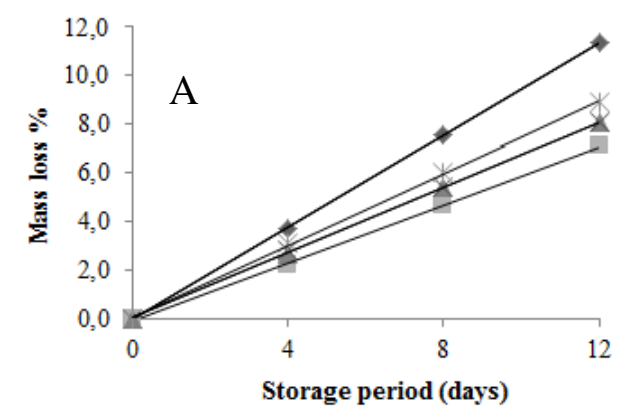

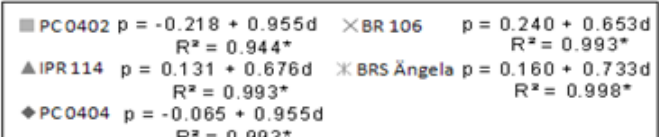

period increased, in both packaging, spikes with and without straw (Figures 1 and 2).

The greatest percentage weight loss regarding the behavior of spikes with straw, PC 0404 variety was highlighted up from the fourth until the $12^{\text {th }}$ day, during storage which losses were 3.75 and $11.39 \%$, respectively (Figure 1A). On the other hand, PC 0402 variety lost less weight in all storage periods, ie, 2.22 and $7.12 \%$ followed by IPR 114 and BR 106 varieties, whose shelf life was longer than the other ones.
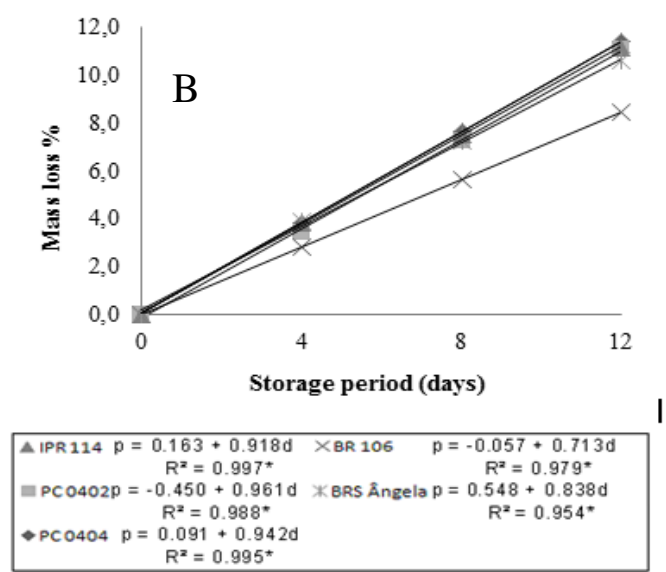

Figure 1. Weight loss (\%) behavior for baby corn spikes with straw (A) and without straw (B) to BRS Angela, PC 0402, PC 0404, IPR 114 and BR 106 varieties stored during twelve days.

The highest weight loss was observed for PC 0404 variety for the spikes storage without straw (Figure 2). While IPR 114 and PC 0402 varieties showed equivalent weight loss in storage period between four and twelve days. On the other hand, BR 106 and BRS Angela varieties showed, respectively, the least weight loss in $0,4,8,12$ day storage periods. Queiroz et al. (2008) studied the weight loss in organic green corn spikes, stored during 12 days at $5{ }^{\circ} \mathrm{C}$ with three varieties, including BR 106, and found out $7.4 \%$ weight loss on the last storage day.

For storage spike without straw (Figure 1B), it was observed the most weight loss for PC 0404 and IPR 114 varieties from 3.85 to $11.39 \%$ and 3.83 to $11.17 \%$, respectively, in storage period between and twelve days. Therefore, BR 106 variety showed the lowest weight loss at storage periods until 12 days, while its losses were 2.79. 5.64 and 8.49\% followed by PC 0402 variety with $3.39,7.23$ and $11.08 \%$, respectively.

\section{Color evaluation}

The color evaluation for $\mathrm{L}^{*}, \mathrm{a}^{*}, \mathrm{~b}^{*}, \mathrm{H}^{*}$ and $\mathrm{C}^{*}$ parameters showed an interaction between variety and wrapping for $L^{*}, a^{*}, b^{*}, C^{*}$. There was also an interaction between variety and storage period in relation to $a^{*}$. Between packaging and storage period for $\mathrm{a}^{*}$ and $\mathrm{C}^{*}$ parameters.

IPR 114 and PC 0402 varieties, in packaging without straw, showed average luminance values $\mathrm{L}^{*}$ higher than the other studied varieties, but they were statistically similar to each other (Table 6). As $L^{*}$ value is a darkening parameter, it is observed darker epidermis in PC 0404, BR106 and BRS Angela baby corn varieties.

Table 6. Interaction sliced among varieties and packaging (with or without straw) for luminance values $L^{*}$ in baby corn spikes stored during twelve days

\begin{tabular}{lcc}
\hline & \multicolumn{2}{c}{ Stored packaging } \\
\cline { 2 - 3 } \multicolumn{1}{c}{ Varieties } & With straw & Without straw \\
\hline PC 0404 & $57.59 \mathrm{Aa}$ & $73.81 \mathrm{Ab}$ \\
IPR 114 & $59.79 \mathrm{Ba}$ & $74.77 \mathrm{Bb}$ \\
\hline
\end{tabular}




\begin{tabular}{lcc}
\hline BRS Ângela & $62.00 \mathrm{Ca}$ & $73.24 \mathrm{Ab}$ \\
BR 106 & $63.42 \mathrm{Da}$ & $73.25 \mathrm{Ab}$ \\
PC 0402 & $63.91 \mathrm{Da}$ & $74.35 \mathrm{Bb}$ \\
\hline
\end{tabular}

Averages followed by the same letter in the column do not differ by themselves according to Scott-Knott test at 5\% probability.

For baby corn spikes packaging with straw, it was observed that PC 0402 and BR 106 varieties showed the highest average values differing from BRS Angela, IPR 114 and the PC 0404. At the end of storage day, the PC0404 variety showed the lowest brightness. The average $\mathrm{L}^{*}$ values for baby corn yield were characterized for their high luminosity. In Figures 2, luminosity value $\left(\mathrm{L}^{*}\right)$ decreased linearly regardless the studied variety and its packaging management. There was a darkening on spikes as the packaging management days increased.

Regarding the intense bright loss for spikes without straw, it was observed that PC 0402 and IPR 114 showed the lowest luminosity losses $\left(\mathrm{L}^{*}\right)$,
74.91 and 73.73 , as well as 75.88 for 73.73 , on 0 and 12th storage day, respectively. As L* value is a darkening indicator, the other varieties presented darker baby corn epidermis.

On straw packaging management, IPR 114 showed the least luminosity loss at each storage period, followed by PC 0404 remaining with the best appearance. On the other hand, BRS Angela showed a superior answer, with little increase of luminosity loss for both studied packaging.

The appearance has great influence in determining the commercial value of a product and it is the most used quality component by consumers. Thus, PC 0402 and BR 106 varieties packed with straw were more suitable in relation to the attribute appearance look for trading purposes.

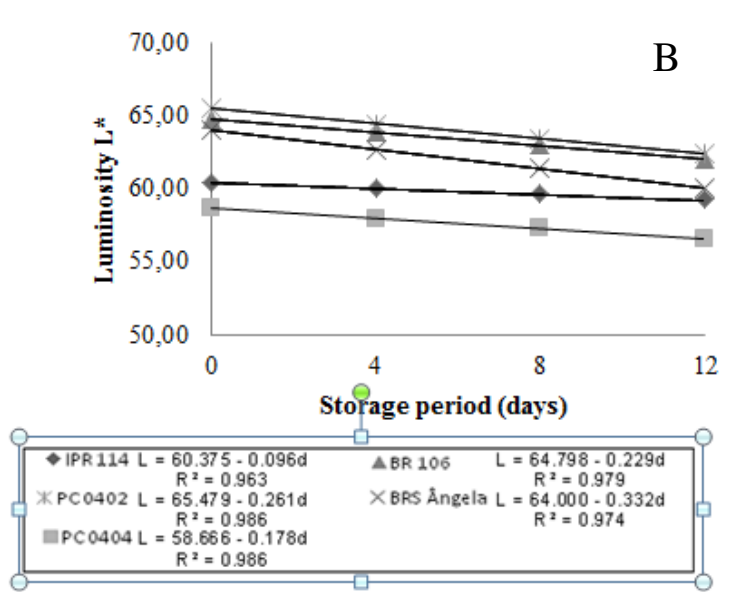

Figure 2. Luminosity behavior ( $\left.\mathrm{L}^{*}\right)$ of baby corn varieties without straw $(A)$ and with straw $(B)$, stored during twelve days.

The $b^{*}$ coordinate refers to the direction that the color can take between blue $\left(-b^{*}\right)$ and yellow $(+b *)$. It was found out that the color value $(b *)$ decreased linearly despite the studied variety (Figures 3).

The BRS Angela and PC 0402 showed the lowest values for spike color changes at 0 to 12 days, ranging from 33.74 to 32.18 and 35.04 to 32.97, respectively, (Figure 3A). These spikelets presented fresh aspects and the yellow color was more intense, in relation to the other varieties with greater color change.

The packaging without straw (Figure 3B) showed that PC 0402 and PC 0404 varieties provided better results regarding the colored maintaining during the storage period values ranging from 37.41 to 35.78 and 36.73 to 35.87 . The studied spikelets shelf-life was longer and did not have any loss on the spikelets visual quality, with less darkening. Mamede et al. (2009) evaluated three temperatures in relation to two corn hybrids quality during eight days of storage. The authors found out that the $b^{*}$ values were 36.46 and 35.49 , respectively. Pinho et al. (2011) studied the color b* in fresh corn grains under organic and conventional systems and recorded average values for $b^{*}$ of 39.62 and 41.45 , respectively. 

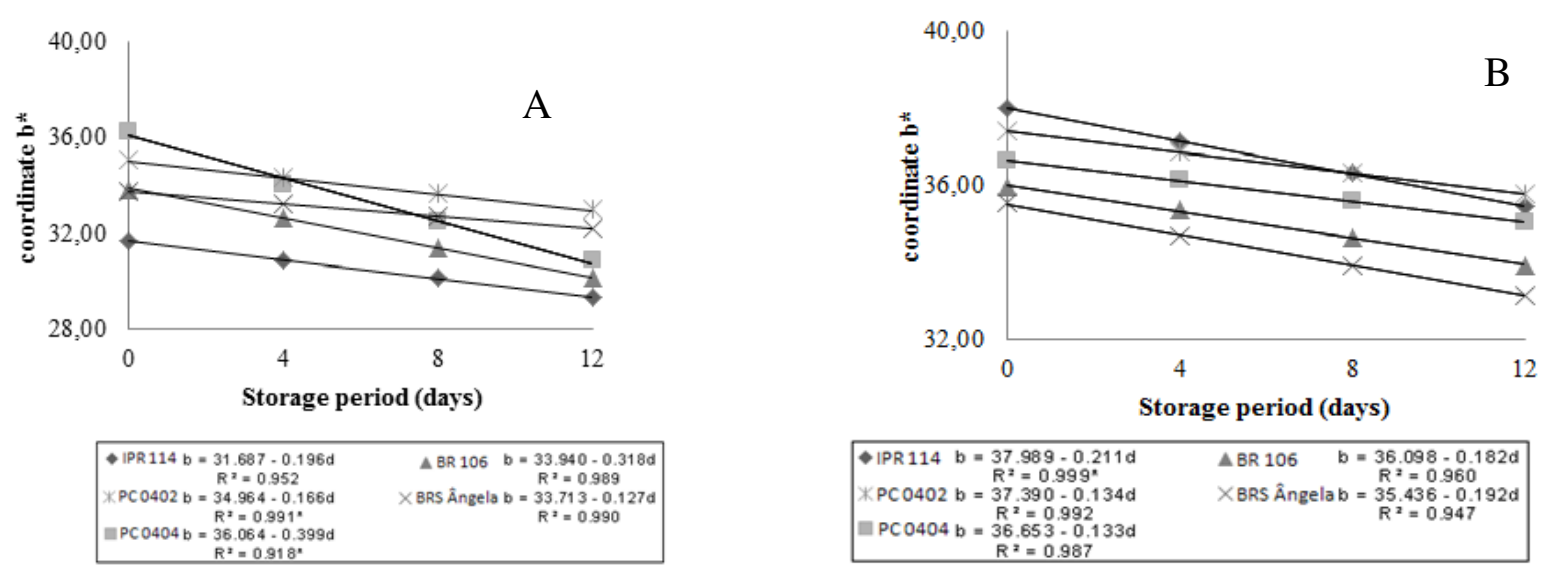

Figure 3. Behavior of $b^{*}$ chromaticity coordinate of baby corn with straw (A) and without straw (B) stored for twelve days.

It can be observed that chromaticity coordinates $\mathrm{a}^{*}$ values ranging from red $(+\mathrm{a})$ to green $(-a)$. They increased during the storage period indicating a trend of change from greenish to brown (Figures 4).

On the other hand, IPR 114 and BR 106 showed less color degradation, for the treatment

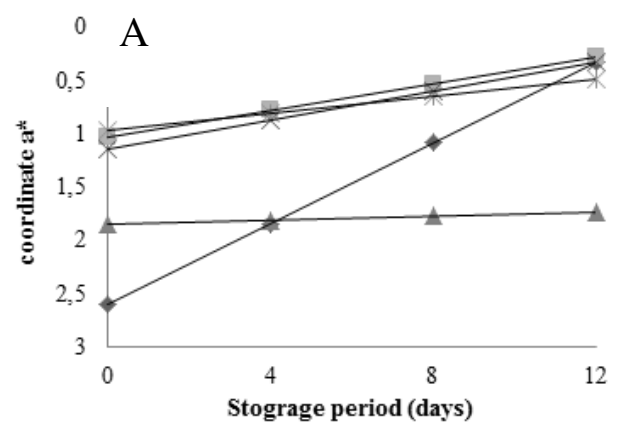

\begin{tabular}{|c|c|}
\hline $\begin{aligned} \text { IPR114 } a= & -2.599+0.189 \mathrm{~d} \\
& \mathrm{R}^{2}=0.952^{*} \\
\text { XPC0402 a } & -0.965+0.040 \mathrm{~d} \\
& \mathrm{R}^{2}=0.998 \\
\text { MPC0404 } \mathrm{a}= & -1.027+0.062 \mathrm{~d} \\
& \mathrm{R}^{2}=0.998^{*}\end{aligned}$ & $\begin{aligned} \triangle B R 106 \quad a= & -1.851+0.081 d \\
& R^{2}=0.944^{\star} \\
\text { X BRS Ángela } a= & -1.151+0.068 d \\
& R^{2}=0.832^{\star}\end{aligned}$ \\
\hline
\end{tabular}

without straw, tending to greenish. But, for the treatment with straw BR 106 variety showed an opposite behavior, since there was a great change; while IPR PC 114 and 0402 showed values closer to greenish.

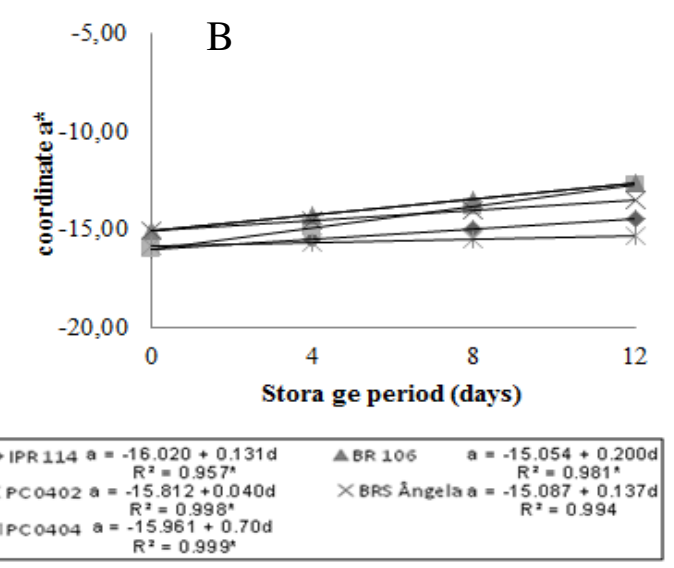

Figure 4. Behavior of $\mathrm{a}^{*}$ chromaticity coordinate $\mathrm{a}^{*}$ of baby corn without straw (A) and with straw (B) stored during twelve days.

Average values for $\mathrm{b}^{*}$ (yellow degree), for packaging without straw of IPR 114, PC 0402 and PC 0404 varieties were higher than the others. These varieties showed statistic difference in relation to BRS Angela and BR 106 varieties, which showed the lowest average values. In packaging with straw, IPR 114 variety presented different answer, with the lowest average value, differing from the other ones, while PC 0402 and BRS Angela showed the highest average values for $b^{*}$ (Table 7).

Table 7. Interaction sliced among varieties and packaging (with or without straw) for chromaticity coordinate $b$ * (yellow degree) in baby corn spikes stored during twelve days

\begin{tabular}{lcc}
\hline & \multicolumn{2}{c}{ Stored packaging } \\
\cline { 2 - 3 } \multicolumn{1}{c}{ Varieties } & With straw & Without straw \\
\hline PC 0404 & $33.25 \mathrm{Ca}$ & $35,85 \mathrm{Bb}$ \\
IPR 114 & $30.51 \mathrm{Aa}$ & $36.66 \mathrm{Bb}$ \\
\hline
\end{tabular}




\begin{tabular}{lll}
\hline BRS Angela & $32.91 \mathrm{Ca}$ & $34.28 \mathrm{Ab}$ \\
BR 106 & $32.02 \mathrm{Ba}$ & $35.00 \mathrm{Ab}$ \\
PC 0402 & $33.96 \mathrm{Ca}$ & $36.58 \mathrm{Bb}$ \\
\hline
\end{tabular}

Averages followed by the same letter in the column do not differ by themselves according to Scott-Knott test at 5\% probability.

The color or tone angle $\left(\mathrm{H}^{*}\right)$ identifies colors as red, green, blue or yellow. The hue angle $\mathrm{H}^{*}$ may vary from 0 to 360 , where 0 corresponds to the red color; 90 to yellow, 180 corresponds to green and 270 to blue. $\mathrm{H}^{*}$ coordinates values decreased linearly with increasing storage period (days), i.e., there was a decrease on color angle (Figures 5). PC 0404 and PC 0402 varieties, on wrapping with straw, showed darker yellow color during storage and IPR 114 showed clearer spikelet. For wrapping without straw, BR 106 variety showed a different behavior, whose color loss was greater. On the other hand, PC 0402 and PC 0404 varieties showed less decreases for color and hue during storage without straw.
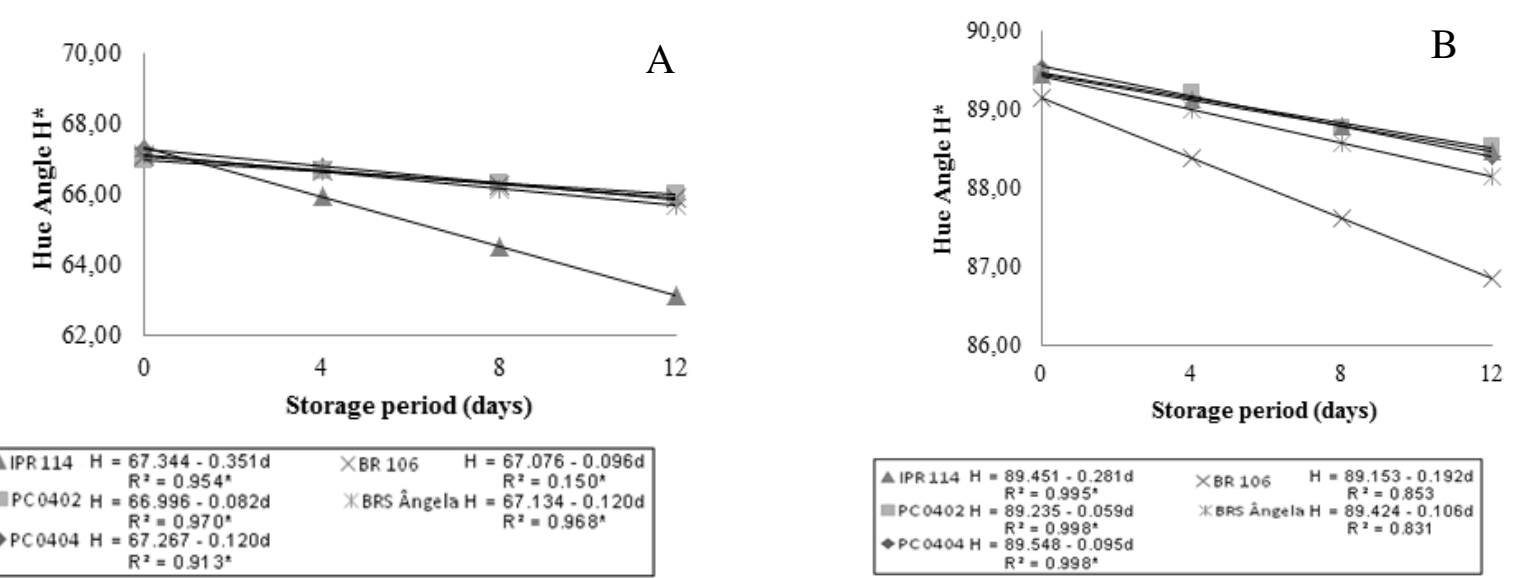

Figure 5. Hue angle $H^{*}$ behavior of baby corn varieties stored with straw (A) and without straw (B) for twelve days.

The PC 0404 and PC 0402 varieties showed the lowest color losses, without straw, during storage from 0 to 12 days. Although, IPR 114 variety showed opposite behavior with further evolution to each storage period. In packaging without straw (Figure 6), it was observed that PC 0402 and PC 0404 varieties provided the best results concerning color retention during storage.
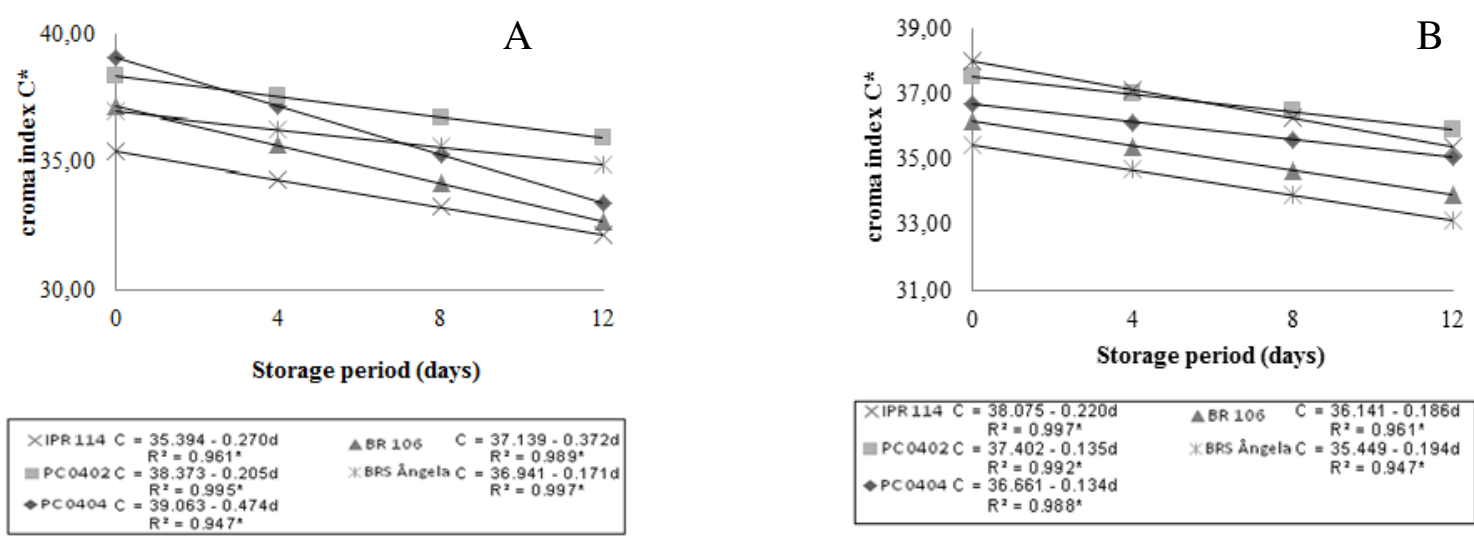

Chroma index $\left(\mathrm{C}^{*}\right)$ indicates the intensity or hue purity. Chroma index decreased throughout the storage period. This indicates a decrease on baby corn color intensity, it was observed for both wrappings. PC 0402 variety maintained the best visual aspect regarding color throughout the studied period (Figure 6).

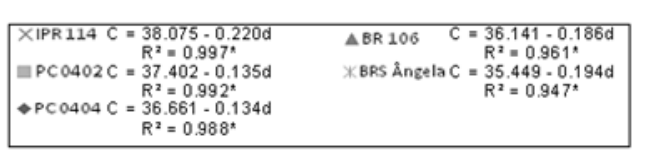

Figure 6. Chroma index $(\mathrm{C} *)$ behavior baby corn varieties stored with straw $(\mathrm{A})$ and without straw $(\mathrm{B})$ for twelve days. 


\section{CONCLUSION}

All the studied varieties were promising for baby corn yield. PC 0404 variety showed the best answers for income and commercial yield of baby corn without straw. There was a linear increase in weight loss of baby corn variety during storage. However, PC 0402 and BR 106 varieties showed weight loss in both wrappings. Thus, they are the most recommended for trading. Among the studied varieties, PC 0402 was the most suitable for trading processing, with the least loss of quality. Finally, in order to delay the postharvest deterioration and protect them against water loss, the best way to pack baby corn is with straw.

RESUMO: Este estudo teve por objetivo avaliar cinco variedades de milho para produção de minimilho e qualidade pós-colheita em sistema orgânico de cultivo. O delineamento experimental utilizado foi inteiramente casualizado com quatro repetições para avaliação dos componentes de produção e para pós-colheita do produto, em arranjo fatorial $5 \mathrm{x}$ $2 \times 4$, sendo as cinco variedades (IPR 114, PC 0402, PC 0404, BR 106 e BRS Ângela) e dois modos de acondicionamento (com palha e sem palha) e tempo de armazenamento (0, 4, 8 e 12 dias) dispostos no delineamento inteiramente casualizado com quatro repetições. Componentes de produção tais como: números de espigas por planta, altura de planta, altura de inserção da primeira espiga, comprimento de espiga sem palha e com palha, diâmetro de espigas com palha e sem palha, massa de espigas com palha e sem palha, produtividade de minimilho com palha e sem palha, produção comercial de minimilho sem palha, rendimento de minimilho comercial foram avaliados e para a pós-colheita do produto foram analisadas: perda de massa e parâmetros de cor ( $\mathrm{L}^{*}, \mathrm{a}^{*}, \mathrm{~b}^{*}, \mathrm{C}^{*}$ e $\left.\mathrm{H}^{*}\right)$ nos tempos de armazenamento 0, 4, 8 e 12 dias. Os resultados obtidos permitiram concluir que as variedades estudadas foram classificadas dentro dos padrões comerciais para diâmetro e comprimento, sendo a PC 0404 a mais indicada para obtenção de minimilho e a PC 0402 a variedade que apresentou melhores resultados para os parâmetros de cor $\mathrm{L}^{*}, \mathrm{a}^{*}, \mathrm{~b}^{*}, \mathrm{C}^{*}, \mathrm{H}^{*}$ e menor perda de massa ao longo do período armazenado.

PALAVRAS-CHAVE: Armazenamento. Componentes de produção. Produtividade.Zea mays.

\section{REFERENCES}

ALMEIDA. I. P. C; SILVA. P. S. L; NEGREIROS. M. Z; BARBOSA. Z. Baby corn. Green ear and grain yield of cultivars. Horticultura Brasileira, Brasília, v. 23, n. 4, p. 960-964, 2005. http://dx.doi.org/10.1590/S010205362005000400020

CAVIGLIONE. J. H.; KILHL. L. R. M.; CARAMORI. P. H.; OLIVEIRA. D.; PUGSLEY. L. Cartas climáticas do Paraná, Londrina: IAPAR, 2000.

EMBRAPA. Centro Nacional e Pesquisa em Solos. Sistema brasileiro de classificação de solos. Brasília: Embrapa-SPI. Rio de Janeiro: Embrapa-Solos, 2009, 412 p.

FERREIRA. D. F. Sistema SISVAR para análises estatísticas: manual de orientação. Lavras: Universidade Federal de Lavras, 2003, 37 p.

HOJO. E. R. D.; CARDOSO. D. A.; HOJO. H. R.; VILAS BOAS. B. V. E.; ALVARENGA. R. A. M. Uso de películas de fécula de mandioca e PVC na conservação pós-colheita de pimentão. Ciência e Agrotecnologia, Lavras, v. 31, n. 1, p. 184-190, 2007.

KADER. A. A. Postharvest technology of horticultural crops. California: University of California, 1992, $226 \mathrm{p}$.

LANA. M. M. Atmosfera modificada e controlada: aplicação na conservação de produtos hortícolas. Brasília. DF: Embrapa Comunicação para Transferência de Tecnologia, Embrapa Hortaliças, 2000, 34 p.

MAMEDE. G. M. A.; CHITARRA. B. A.; FONSECA. O. J. M.; SOARES. G. A.; FERREIRA. S. C. J.; LIMA. O. C. L. Conservação pós-colheita de espigas de milho verde minimamente processado sob diferentes temperaturas. Ciência e Agrotecnologia, Lavras, v. 33, n. 1, p. 200-206, 2009. 
MENEGHETTI. A. M.; NÓBREGA. L. H. P.; SANTOS. R. F. Manejo da irrigação para a produção de minimilho por evapotranspiração. Engenharia na Agricultura, Viçosa, v. 16, n. 3, p. 351-358, 2008.

MENEGHETTI. A. M.; SANTOS. R. F.; NÓBREGA. P. H. L.; MARTINS. I. G. Análise de crescimento de minimilho submetido a lâminas de irrigação. Acta Scientiarum Agronomy, Maringá, v. 30, n. 2, p. 211-216, 2008.

PEREIRA, R. S. Desempenho agronômico e forrageiro de minimilho e milho verde em diferentes épocas de semeadura e idades de corte das plantas remanescentes. 2011. 113 p. Dissertação (Mestrado-Programa de Pós-Graduação em Produção Vegetal no Semiárido) - Universidade Estadual de Montes Claros, Janaúba, Minas Gerais. 2011.

PEREIRA FILHO. I. A.; CRUZ. J. C. Manejo Cultural de Minimilho. Embrapa, Circular Técnica, n. 7, 4p., 2001.

PEREIRA FILHO. I. A.; GAMA. E. E. G. Avaliação de genótipos de milho em diferentes densidades de semeadura visando à produção de minimilho com maior aproveitamento comercial. Sete Lagoas: EmbrapaCNPMS, Comunicado Técnico, n. 29, 4p., 2001.

PEREIRA FILHO. I. A. Minimilho: cultivo e processamento. Sete Lagoas: Embrapa Milho e Sorgo, 2008, $244 \mathrm{p}$.

PEREIRA FILHO. I. A.; CRUZ. J. C.; QUEIROZ. V. A. V.; CAXITO. A. M.; LEITE. C. E. P.; CARMO. Z. C. Avaliação de cultivares de milho visando à produção de minimilho na região Norte do Estado de Minas Gerais. In: EMBRAPA. Centro Nacional de Pesquisa de Milho e Sorgo. Sete Lagoas: Embrapa-CNPMS. Circular Técnica, n. 131, 5p. 2009.

PINHO. R. G. V.; CARVALHO. G. S.; RODRIGUES. V. N.; PEREIRA. J. Características físicas e químicas de cultivares de milho para produção de minimilho. Ciência e Agrotecnologia, Lavras, v. 27, n. 6, p. 1419$1425,2003$.

PINHO. L.; PAES. M. C. D.; GLÓRIA. M. B. A.; ALMEIDA. A. C.; COSTA. C. A. Color and chemical composition and of green corn produced under organic and conventional conditions. Ciência e Tecnologia de Alimentos, Campinas, v. 31, n. 2, p. 366-371, 2011. http://dx.doi.org/10.1590/S0101-20612011000200014

QUEIROZ. V. A. V.; MORAES. A. E.; QUEIROZ. R. L.; TARDIN. D. F. GUEDES. O. E. PEREIRA FILHO. I. A.; LOMBARDI. T. C. Utilização de cobertura comestível na conservação pós-colheita de minimilho minimamente processado. Ciência e Tecnologia de Alimentos, Campinas, v. 30, n. 4, p. 910-916, 2010. http://dx.doi.org/10.1590/S0101-20612010000400012

QUEIROZ. V. A. V; QUEIROZ. L. R; MATRANGOLO. W. J. R; TARDIN. F. D; PEREIRA FILHO. I. A; CRUZ. J. C. Perda de massa no armazenamento de espigas de milho verde orgânico. In: Congresso Nacional de Milho e Sorgo, 27, 2008, Londrina. Anais... Londrina: UEL, 2008.

RAUPP. D. S.; GARDINGO. J. R.; MORENO. L. R.; HOFFMAN. J. P. M.; MATIELLO. R. R.; BORSATO. A. V. Minimilho em conserva: avaliação de híbridos. Acta Amazônica, Manaus, v. 38, n. 2, p. 509-516, 2008.

RODRIGUES. L. R. F.; DA SILVA. N.; MORI. E. S. Avaliação de sete famílias s2 prolíficas de minimilho para a produção de híbridos. Bragantia, Campinas, v. 63, n. 1, p. 31-38, 2004.

http://dx.doi.org/10.1590/S0006-87052004000100004

SÁ. M.; RAMALHO. M. A. P.; SOUZA SOBRINHO. F. Aspectos morfológicos e fisiológicos de cultivares modernas e antigas de milho. Ciência e Agrotecnologia, Lavras, v. 26, n. 5, p. 1082-1091, 2003. 